\title{
ANALYSIS OF INTERLINGUAL ERRORS IN ENGLISH IN ELEMENTARY SCHOOL STUDENTS
}

\author{
Kadek Adyatna Wedananta \\ Universitas Pendidikan Nasional \\ adyatnawedananta@undiknas.ac.id
}

\begin{abstract}
ABSTRAK
This study analyzed such interlanguage errors in five private English students with low school grades. That is why some of these students' interlingual errors are easy to spot. The use of English must take place during a private course in English. This can happen from teacher to student or from student to teacher, or it can occur when certain written activities are completed by students. This study found evidence that English was still used at the Interlanguage (IL) level because although they used English, some students still had interlingual errors, such as the use of to be, prepositions and adjectives/nouns, etc. This study also found a technique by which teachers solve the interlingual error problem by using Drill method, which allows them to repeat the use of to be, adjectives, etc.
\end{abstract}

Keywords: Second Language Acquisition, Interlingual Errors, Drill Method

\section{INTRODUCTION}

The acquisition of a second language or learning a second language is the process by which people learn a second language. Acquisition of a second language (often abbreviated as SLA) also refers to the discipline devoted to studying that process. Second language refers to any language learned in addition to one's first language; although this concept is named secondlanguage acquisition, it can also incorporate learning a third, fourth, or next language. Second language acquisition refers to what the learners are doing; it does not refer to practices in language teaching. In essence, language is signs and symbols that represent something that is expressed, both spoken and written (Swarniti \& Yuniari, 2019).

In addition, Second Language Acquisition (SLA) is the study of individuals and groups who learn the next language for their first learning young children, and for the process of learning those languages. Additional languages are called second languages (L2), although they can actually be third, fourth, or tenth to be 
obtained. It is also commonly called the target language (TL), which refers to any language that has the aim or purpose of learning. The scope of SLA includes informal L2 learning that occurs in a naturalistic context, formal L2 learning that occurs in a classroom, and L2 learning which involves a mixture of these settings and circumstances (Troike, 2006).

In fact, attempts to describe the language of learners are based on comparing different languages and on error analysis of learners. However, this approach is not able to predict all the mistakes that students make while in the second language learning process. For example, a Javanese speaker learning English might say "What is Suparman doing?", Even though this is not a valid sentence in either language.

In order to explain the types of systematic error, this cross-language idea was developed. Interlanguage is a language system that comes to the mind of second language learners. The learner interface is not a less learned version of the language riddled with random errors, nor is it a language based purely on the errors introduced from the learner's first language. Rather, it is a language unto itself, with its own systematic rules. It is possible to view most aspects of language from an inter- lingual perspective, including grammar, phonology, lexicon, and pragmatics.

In addition, according to Later, James (1998), in his study, showed various types of mistakes of students related to negligence, overinclusion, misselection (using the wrong words instead of the wrong form), misordering, blends (mixing appears when two alternative grammars the shapes are combined to produce an ungrammatical mixture.)

In addition, according to Keshavarz's taxonomy of sources of error, interlingual errors result from the transfer of phonological, morphological, grammatical, lexiconintant, and stylistic elements from the learner's mother tongue to the target language learning.

However, because this study has limitations in conducting research, this study only focuses on interlingual errors.

Based on this explanation, this study analyzed several interlingual errors that occur in five English course students who have low scores in their schools. That's why it was easy to spot some of the interlingual errors of these five students. In addition, the use of second language acquisition or the use of L2 often occurs in the classroom when they are studying L2, especially English. This can happen from teacher to 
student or student to teacher or can see when a student has created some assignment or written assignment.

Therefore, several questions arise that will be the key to this research, namely: (1) What interlingual errors did five English course students who had low scores in their school? (2) What were the strategies used by the teacher in solving these errors?

With the emergence of questions that form the problem formulation, the objectives of this study will emerge as follows: (1) To find out interlingual errors made by five English course students who have low scores in their schools, and (2) To find out the strategies used by the teacher in solving these errors. It aims to find the gaps, strength, and weakness. It is helpful for this research to fill in the gaps and to be a different research (Wayan Swarniti, 2019).

\section{LITERATURE REVIEW}

This study used several literature reviews to strengthen this research from a theoretical aspect. The theories used are as follows: According to later, James (1998), in his study, showed various types of mistakes of students related to negligence, overinclusion, misselection (using wrong words instead of wrong forms), misordering, blends ( blending arises when two alternative grammatical forms are combined to produce an ungrammatical mixture.) Based on this, he states that there are four causes for error.

a. Interlingual errors (mother-tongue influence): the types of errors affected by the native language that interfere with learning the target language.

b. Intralingual error: this type of error is caused by the target language itself such as: false analogy, misdiagnosis (students form wrong hypotheses), incomplete application of rules (this is the opposite of overgeneralization or one might call it culturing because learners don't use all regulations), Utilization of redundancy (this error occurs with a considerable amount of redundancy. It is shown throughout the system in the form of morphology and unnecessary double signals), Overcoming co-event boundaries (this error is caused by extraordinary regulation) Hypercorrection or Excessive monitoring (this results from learners' more careful and strict adherence to rules), overgeneralization or system-oversimplification (this error is caused by misuse of words or grammar rules).

c. Fault-based communication strategies are divided into holistic strategies or 
approaches and analytic strategies or strategies.

d. Errors caused by errors are the result of being misled by the way in which the teacher provides definitions, examples, explanations and arranges opportunities for practice. In other words, mistakes are mostly caused by the teaching and learning process as follows: Errors caused by material, errors caused by the Teacher, errors due to practice, Errors caused by pedagogical priorities, Look-up errors.

\section{METHODS}

The subjects who participated in this survey were five English course students who had low scores in their schools.

Table 1: List of five students who have scored low in the English course at their school.

\begin{tabular}{|l|l|l|l|}
\hline No & Name & Grade & Note \\
\hline 1 & Adi & 6 & \\
\hline 2 & Budi & 6 & \\
\hline 3 & Desi & 6 & \\
\hline 4 & Iwan & 6 & \\
\hline 5 & Roni & 6 & \\
\hline
\end{tabular}

Another subject is the English teacher who will be interviewed about what methods he will use to solve this problem.

This study used a qualitative descriptive research design in which researchers took data directly from students by collecting assignments, analyzing assignments and interviewing English teachers. The research material used was writing composition. Students write by explaining the topic of a funny film / cartoon / in the last seen TV program. "Movies are chosen because films or films are entertainment for children who are 
usually interested in writing about activities in their spare time. In addition, descriptive themes ask students to use different verbal tenses and accuracy in vocabulary usage.

Researchers observe the school and observe the scores of all students who will be candidates for this research or research. Students are asked to write a composition during the last

\section{FINDING AND DISCUSSION}

For the findings of this study, the researchers found that there were interlingual twenty minutes of their English class. They did not know beforehand that they had to do this class assignment. The researcher interviewed the English teacher and made a discussion about what strategies should be used to solve the problem. Researchers transcribe all data (written composition by students and results of interviews with English teachers).

errors in the written composition (descriptive text) made by five students, as follows:

Table 2: Interlingual errors of written composition (descriptive text) made by five low-scoring English course students at school.

\begin{tabular}{|l|l|l|l|}
\hline No & Name & Interlingual Error in Sentence & Interlingual error type \\
\hline 1 & Adi & "Upin and Ipin sad" & there is no "To be" in L1 \\
\hline 2 & Budi & "Spongebob happy" & there is no "To be" in L1 \\
\hline 3 & Desi & $\begin{array}{l}\text { Spiderman talk in the } \\
\text { telephone }\end{array}$ & $\begin{array}{l}\text { interlingual errors in } \\
\text { prepositions }\end{array}$ \\
\hline 4 & Iwan & $\begin{array}{l}\text { "Grizzly, Panda, and Ice Bear } \\
\text { go to school in 8 o" clock" }\end{array}$ & $\begin{array}{l}\text { interlingual errors in } \\
\text { prepositions }\end{array}$ \\
\hline 5 & Roni & "Shiva has a bicycle red" & $\begin{array}{l}\text { Interlingual errors in word } \\
\text { placement }\end{array}$ \\
\hline
\end{tabular}


The next finding is about the English teacher's comments about the above results. And he did not forget to convey that the strategy that could be used for these students was the drill method which gave them repetitions about the use to be done, the correct pronouns and adjectives / nouns, the use of to be, etc.

Based on the above findings, the researcher conducted the following discussion: The first analysis was about interlingual errors where L1 did not have "To Be" in making a sentence. It happened to two students, namely Adi and Budi. One example is "Spongebob happy", in English before happy, students have to put "To Be" "is" because there is no verb in the sentence. The second analysis is about interlingual errors in prepositions which are quite problematic for native speakers. The main mistakes involved in the $\mathrm{L} 1$ transfer rules. It happened to two students, namely Desi and

\section{CONCLUSION}

This study analyzed several interlingual errors that occurred in five English course students who had low scores in their school. That's why it's easy to spot some of the Interlingual mistakes of the five students. The use of English (L2) certainly occurs in English classrooms. This can happen from teacher to
Iwan. One example is "Captain America and Spiderman talk on the telephone. The preposition "in" in this sentence means "in" in Indonesian (L1) but in English (L2) if we say or do something using the telephone, we have to replace "in" with "on". The third analysis is about interlingual errors in using adjective / noun sequences, in Indonesian (L1), qualifying adjectives are usually used after nouns, but in English (L2) it's not like that. It happened to a student named Roni. An example is "Shiva has a bicycle red". If we use the rule of bahasa Indonesia (Indonesian/ L1), it must be true, but in English (L2) it should be ".... a red bicycle".

The final analysis should be about the strategy used after finding the error, according to the English teacher, the strategy that can be used for this student is the Drill method which gives them repetitions of correct usage, pronouns and adjective / noun sequences, etc.

student or student to teacher or can see when a student has created some assignment or written assignment. This study found evidence that the English (L2) used is still at the inter-language level (IL) because some students still have Interlingual errors when they use English (L2) such as the use of $\mathrm{To} \mathrm{Be}$, prepositions and adjective / noun sequences. Therefore, the 
researcher found a strategy from the school teacher to solve this interlingual error problem by using the Drill method which made them repeat the use of $\mathrm{To} \mathrm{Be}$, the correct order of adjectives / nouns, etc.

Research has limited other approaches to the theory of interlingual error. A

\section{REFERENCE}

Brown, H, Douglas (2000) Prinsip Bahasa dan Pengajaran. Addison Wesley: Longman

$\begin{array}{lll}\text { Corder, } & \text { SP } & \text { (1967). Signifikansi }\end{array}$ kesalahan pembelajar.

Donovan, Melissa (2007) 12 Kebiasaan Menulis Penting untuk Memperkuat Keterampilan Anda. Tersedia di http://www.writingforward.com/betterwriting/writing-habits.

Dullay, Heidi (1983) Bahasa Dua. New York: Oxford University Press

Ellis, Rod (1994) Studi tentang akuisisi bahasa kedua. Oxford: OUP

Harmer, Jeremy (1983) Praktik Pengajaran Bahasa Inggris. London: Longman

Hubbard, Petter (1983)A Course Training Untuk TEFL, Oxford: Oxford University Press

Jack C. Richards, C., J dan Rodgers (1999). Pendekatan dan Metode dalam Pengajaran Bahasa (Edisi Kedua). Cambridge: Cambridge University Press recommendation for future research is to include another approach to interlingual error theory, and to use a more specific analysis.

James, C. (1998). Kesalahan dalam pembelajaran dan penggunaan bahasa: Menjelajahi Analisis Kesalahan. London: Longman.

Keshavarz, MH (1994). Analisis kontrastif dan analisis kesalahan. Publikasi Rahnama.

Larsen-Freeman, D dan MHLong (1991). Pengantar untuk penelitian akuisisi bahasa kedua. London: Longman

Myers, Jerome L. (2010). Desain penelitian dan Analisis Statistik. New York: Routledge.

Norris, John (1983) Bahasa Pelajar dan Mereka Kesalahan. New York: Macmillan

Santika, I Gusti Ngurah. 2017. Kepala Sekolah Dalam Konsep Kepemimpinan Pendidikan: Suatu Kajian Teoritis. Widya Accarya. 7 (1). Swarniti, N. W., \& Yuniari, N. M. (2019). Keberadaan Leksikon Pohon Langka di Denpasar: Studi Ekolinguistik. Seminar Nasional INOBALI 2019 Inovasi Baru Dalam Penelitian Sains, Teknologi Dan Humaniora, 405-411.

https://eproceeding.undwi.ac.id/index.php/inob ali/article/view/180

Wayan Swarniti, N. (2019). The Translation 
WIDYA ACCARYA: Jurnal Kajian Pendidikan FKIP Universitas Dwijendra

Vol 11 No 2, Oktober 2020

PISSN: 2085-0018 E-ISSN: 2722-8339

Available Online at http://ejournal.undwi.ac.id/index.php/widyaaccarya/index

Procedures of Bible Translation. 5(2), 187-

196. https://doi.org/10.22225/jr.5.2.1277.187196

Trawinsky, Mariusz (2005) Garis besar teori akuisisi bahasa kedua. Krakow: Naukowe Akademi Pedagogieznej
Troike, S. Muriel (2006). Pendahuluan Akuisisi Bahasa Kedua. Cambridge: Cambridge University Press. 